\title{
PENJUALAN ONLINE MELALUI WEBSITE E-COMMERCE BERBASIS CONTENT MANAGEMENT SISTEM PADA TOKO DETAK ORIGINAL
}

\author{
Yesi Puspita Dewi 1), Rizki Adhi Prawitama 2), Muhammad Faqih Firdaus ${ }^{3)}$, \\ Reza Bayu Perdana 4) \\ ${ }^{\left.1-3^{*}\right)}$ Program Studi Sistem Informasi, Fakultas Teknologi Informasi \\ Universitas Budi Luhur
}

Jl. Ciledug Raya, Petukangan Utara, Jakarta Selatan 12260

\begin{abstract}
Abstrak : Toko Detak Original merupakan sebuah toko yang melayani penjualan pakaian terutama kemeja di daerah Tanah Abang, Jakarta Pusat. Toko Detak Original menjalankan bisnisnya dengan melakukan penjualan secara offline di bangunan toko yang ada saat ini dan ruang lingkup yang masih terbatas dan promosi cenderung pasif, sehingga Toko Detak Original belum dikenal dapat oleh masyarakat secara luas. Selain itu, laporan pembukuan dan penjualan dilakukan dicatat pada sebuah buku sehingga sangat rentan terjadi kekeliruan pencatatan, kesulitan dalam melakukan pencarian transaksi pembelian yang sudah dilakukan juga melakukan perhitungan rekap penjualan yang terjadi. Toko Detak Original dapat meningkatkan profit yang didapatkan apabila dapat mengatasi masalah yang disebutkan diatas. Atas dasar masalah tersebut, pada penelitian ini dibangun sebuah website Toko Detak Original berbasis E-Commerce yang dapat menampilkan profile produk yang dijual dan menangani penjualan secara online. Dengan website tersebut Toko Detak Original dapat mengatasi masalah yang dialami, karena pelanggan dapat melihat produk secara online dengan device yang terhubung dengan internet, melakukan pembelian langsung pada halaman website tanpa harus datang ke bangunan toko, tentunya hal ini membuat suatu aktivitas menjadi sangat efisien dan meningkatkan profit bagi Toko detak Original.
\end{abstract}

Kata Kunci : E-commerce, Online, Penjualan Online, Toko, Website

\begin{abstract}
Toko Detak Original is a store that sells clothing, especially shirts in Tanah Abang region, Central Jakarta. Toko Detak Original runs its business by selling offline at the current store building and promotions tend to be passive, so Toko Detak Original is not widely known by the public. In addition, bookkeeping and sales reports are recorded in a physical book so that it is very vulnerable to recording errors, difficulties in searching for purchase transactions that have been carried out as well as calculating sales recaps that have occurred. Toko Detak Original can increase the profit obtained if it can overcome the problems mentioned above. On the basis of these problems, in this study, an E-Commerce-based Toko Detak Original website was built that can display product profiles that are sold and handle online sales. With this website, Toko Detak Original can overcome the problems experienced, because customers can view products online with devices connected to the internet, make purchases directly on the website page without having to come to the store, of course this makes an activity very efficient and increases profits for the Toko Detak Original.
\end{abstract}

Keywords: E-Commerce, Online, Online Store, Website 


\section{PENDAHULUAN}

Pakaian adalah salah satu kebutuhan pokok, sehingga manusia dari belahan dunia manapun memerlukan kan pakaian. Hal ini menjadi peluang usaha untuk menjual pakaian tidak hanya di tempat kita berada tetapi ke seluruh tempat dimanapun. Hal ini memungkinkan dengan berkembangnya teknologi internet. sehingga penjualan dapat dilakukan secara online dan pembeli dapat melakukan pembelian dari manapun selama terhubung dengan internet dengan E-Commerce.

E-Commerce adalah pembelian atau penjualan barang maupun jasa, yang dilakukan melalui komputer dengan menggunakan media jaringan. ECommerce suatu cara atau proses jual beli secara elektronik yang memanfaatkan fasilitas jaringan internet dimana terdapat website yang dapat menyediakan layanan mendapatkan dan mengirimkan secara online. E-Commerce akan merubah kegiatan marketing juga sekaligus memangkas biaya operasional untuk kegiatan perdagangan.

Toko Detak Original merupakan sebuah toko yang melayani penjualan kemeja di Tanah Abang, Jakarta Pusat. Toko Detak Original melakukan penjualan secara offline dan ruang lingkup penjualan dan pemasaran nya masih terbatas dimana pembeli harus datang langsung ke toko untuk melihat produk yang dijual dan melakukan pembelian. Kegiatan promosi yang dilakukan masih sekitar toko. Toko Detak Original kesulitan untuk memasarkan atau menjual produk ke luar kota dan wilayah lainnya, hal itu berdampak pada kurang maksimalnya pemasukan toko. Masalah tersebut harus diatasi sehingga toko mudah dalam memasarkan produk dan memberikan informasi produk sehingga menarik minat
Jurnal IImu Komputer dan Informatika Vol 2 No 2 p-ISSN: $2776-7418$ e-ISSN: 2746-508X

pembeli baik dari dalam maupun dari luar wilayah.

Pada penelitian ini dibangun sebuah website penjualan dan pemesanan berbasis E-Commerce pada Toko Detak Original sehingga penjualan pada Toko Detak Original dapat meningkat karena pelanggan dapat melihat produk Kemeja dimana saja dan kapan saja. Produk dijual secara online dan melakukan pembelian langsung tanpa harus datang ke toko, tentunya hal ini membuat suatu aktivitas menjadi sangat efisien.

\section{KAJIAN PUSTAKA DAN LANDASAN TEORI}

\section{Perancangan Sistem}

Perancangan sistem adalah merupakan penggambaran, perencanaan, dan pembuatan sketsa atau pengaturan dari beberapa elemen terpisah menjadi elemen yang utuh dan berfungsi. Tujuan dari perancangan sistem, yaitu untuk memberikan gambaran secara jelas dan rancang bangun yang lengkap kepada pembuat program komputer untuk memenuhi kebutuhan pengguna.

Tahapan dalam perancangan sistem mencakup analisis sistem, perancangan konseptual, fisik, implementasi, konversi, operasi dan pemeliharaan. Alat yang digunakan pada tahap perancangan sistem adalah rancangan class diagram, rancangan dialog layar, dan sequence diagram. Pada perancangan sistem dibuat secara singkat dari keseluruhan screen yang ada pada sistem. Perancangan tersebut meliputi perancangan antarmuka aplikasi dan perancangan proses.

\section{E-Commerce}

E-commerce adalah penggunaan jaringan komunikasi dan komputer untuk melaksanakan proses bisnis. E-commerce merupakan strategi komersial baru yang mengarah pada peningkatan kualitas produk, layanan dan perbaikan ditingkat 
p-ISSN: $2776-7418$ e-ISSN: 2746-508X

pelayanan penyediaan sementara link persyaratan organisasi, pemasok, dan konsumen ke arah mengurangi biaya (Rachman, 2017).

Manfaat dari penggunaan e-commerce diantaranya adalah perusahaan dapat memiliki sebuah pasar internasional, biaya operasional menurun, waktu proses semakin cepat dan mengurangi resiko human error, Mengurangi penggunaan kertas dalam mendesain, memproduksi, pengiriman, pendistribusian hingga pemasaran.

E-commerce memiliki alur kegiatan yang melibatkan empat komponen, yang pertama adalah pihak penjual dapat berupa pemilik toko online bersangkutan atau sejumlah pelaku usaha, pihak yang memiliki peran penting dalam menjalankan sebuah bisnis e-commerce, dan satu lagi adalah teknologi.

\section{Perancangan Basis Data}

Menurut (Fathansyah, 2015) basis data adalah kumpulan data komputer yang terintegrasi, diorganisasikan dan disimpan dan data tersebut dapat diambil kembali. Tahapan basis data dengan desain konseptual adalah tahapan dimana spesifikasi sistem secara lengkap dibuat berdasarkan kebutuhan yang telah dianalisa dan direkomendasikan pada tahap sebelumnya.

Terdapat dua komponen yaitu desain database logis dan desain hirarki menu. Desain database pada tahap konseptual dilakukan dengan data modeling yang digambarkan dengan ERD (Entity Relationship Diagram), sedangkan process modeling digambarkan dengan diagram use case, diagram konteks, dan DFD (Data Flow Diagram).

\section{Implementasi Sistem}

Menurut (Julianto, 2018) implementasi sistem merupakan tahapan dalam menerapkan sistem yang telah dibangun, dimana nantinya akan diketahui kualitas dari sistem yang dirancang, apakah sudah berjalan dengan baik dan sesuai dengan tujuan yang diharapkan.

Implementasi program bukan hanya memasukkan komponen yang ada ke dalam software, tetapi juga bagaimana mengatur antara kesesuaian program dan rancangan yang telah dibuat. Pada tahap ini terdapat dua bagian.

Pembuatan database dilakukan sebelum penginstalan opencart. Pembuatan database digunakan untuk memasukkan, menghapus, mengubah, memanipulasi, dan memperoleh data seluruh content yang ada di website e-commerce.

Implementasi user interface pada opencart ditujukan supaya pengguna lebih mudah untuk mengakses website e-commerce. Implementasi ini didasarkan atas desain yang telah dibuat pada tahapan physical design.

\section{METODE}

\section{Analisa Situasi}

Dalam tahap analisis situasi, peneliti melakukan pertemuan secara rutin dan seksama dengan pihak Toko Detak Original untuk menganalisa kebutuhan dan melakukan wawancara / diskusi langsung mengenai target dan tujuan terhadap pemanfaatan teknologi terkini dalam menghadapi permasalahan yang dihadapi.

\section{Identifikasi Masalah}

Dalam tahapan identifikasi permasalah yang dialami oleh Toko Detak Original yaitu belum memiliki media yang menampilkan informasi product, tempat untuk proses jual beli secara online serta sarana promosi.

\section{Menentukan Tujuan}


Dalam tahapan ini ditentukan tujuan dari penelitian yang fokus utamanya dapat memecahkan atau mengatasi masalah yang dialami oleh Toko Detak Original. Didapati tujuan penelitian yaitu menjadikan website sebagai media promosi sekaligus menampilkan informasi product, tempat untuk proses jual beli secara online untuk Toko Detak Original.

\section{Rencana Pemecahan Masalah}

Dalam tahapan ini peneliti melakukan studi bagaimana cara memecahkan masalah yang dihadapi Toko Detak Original. Hal ini dilakukan dengan cara melihat langsung sumber-sumber dokumen yang terkait berupa sumber tertulis maupun elektronik. Dokumen ini mengacu pada literatur berupa buku yang memuat teori pendukung maupun penelitian serupa yang sudah pernah dilakukan, baik yang berhasil maupun mendapatkan hasil kurang memuaskan sehingga bisa dijadikan pelajaran.

Pemecahan masalah dibagi kedalam dua tahap sehingga tepat sasaran dan sesuai dengan kebutuhan Toko Detak Original. Hal tersebut yaitu membangun website menggunakan pemrograman PHP dan melakukan pelatihan kepada pihak pengelola Toko Detak Original agar mengerti cara penggunaan website.

\section{Implementasi dan Evaluasi}

Pada tahap evaluasi juga kegiatan dibagi menjadi dua tahapan yaitu melakukan pengujian terhadap website menggunakan Blackbox Testing sebelum dibuat digunakan. Yang kedua adalah melakukan pengujian validasi, yaitu kesesuaian antara permintaan pihak komunitas dengan program yang telah dibuat sesuai dengan kebutuhan fungsionalnya.
Jurnal IImu Komputer dan Informatika Vol 2 No 2 p-ISSN: $2776-7418$ e-ISSN: 2746-508X

Pemodelan sistem dapat digambarkan dengan beberapa diagram yang akan dideskripsikan pada bagian dibawah ini. Hubungan antara actor dan aktivitasnya dapat dilihat pada Use Case diagram dibawah ini.

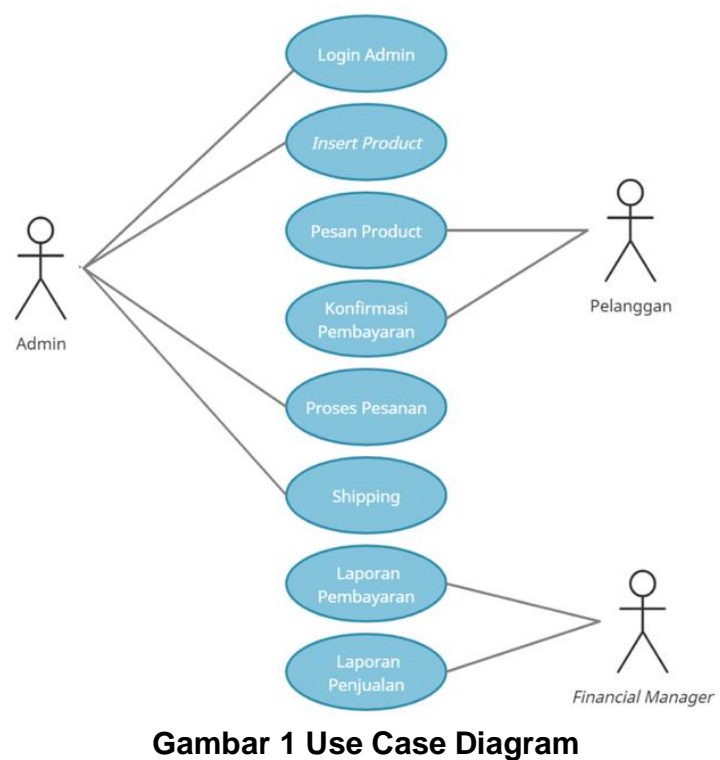

Hubungan antara entitas yang akan menjadi basis data dapat dilihat pada Class Diagram sesuai gambar dibawah ini.

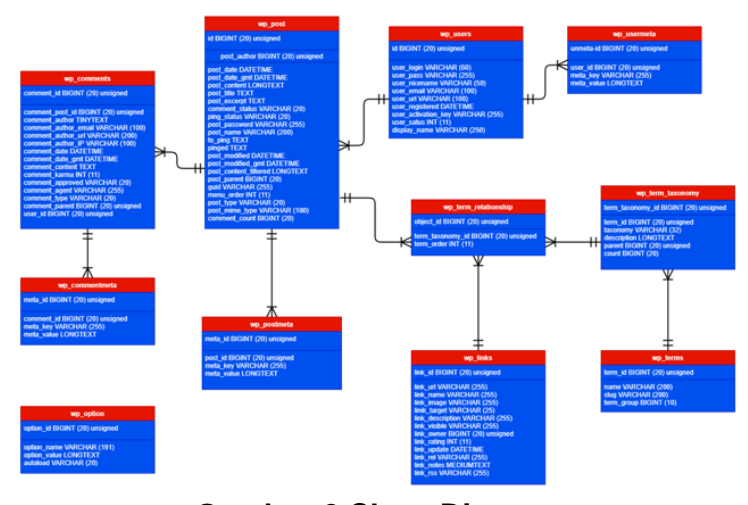

Gambar 2 Class Diagram

Rancangan basis data yang digunakan dapat dilihat pada Logical Record Structure (LRS) yang digambarkan dibawah ini. 


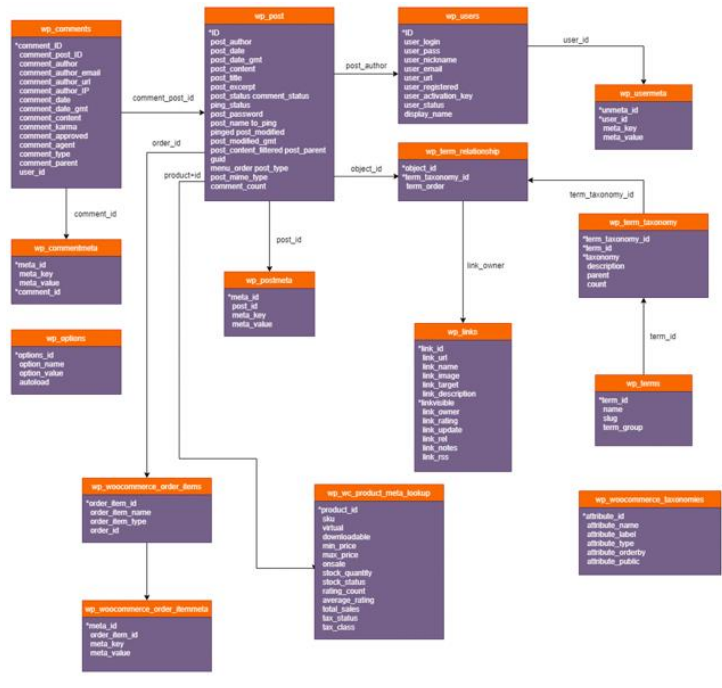

Gambar 3 Logical Record Structure

Tampilan layar website dapat dilihat pada gambar-gambar dibawah ini. Saat pertama kali website diakses akan menampilkan halaman depan seperti berikut.

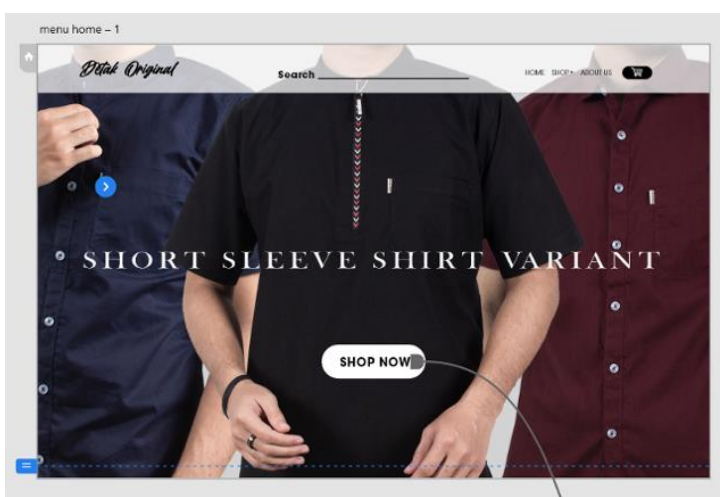

Gambar 4 Tampilan halaman depan

Untuk melihat daftar barang yang dijual atau katalog dapat mengunjungi halaman shop. Pada halaman ini pengunjung dapat melihat variasi dan jenis barang yang dijual.

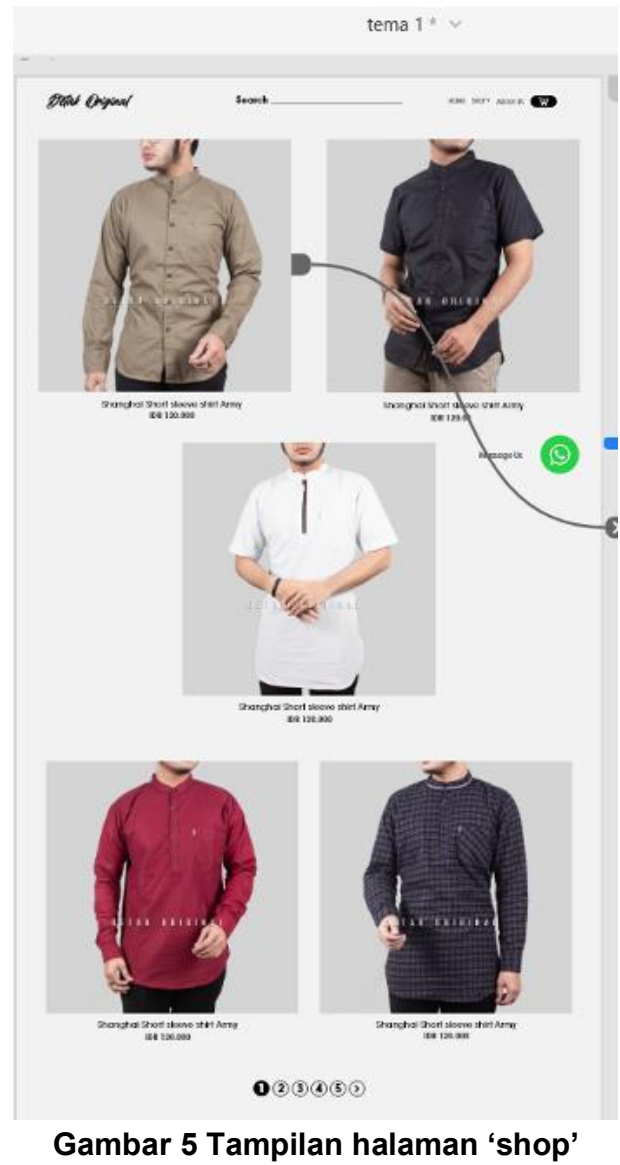

Apabila pengunjung menginginkan informasi detail mengenai satu produk, maka pengunjung perlu melakukan klik pada salah satu gambar produk yang akan mengalihkan pengunjung pada halaman detail produk. Pada halaman ini ditampilkan detail berupa gambar yang lebih mendetail dari berbagai sudut pandang, detail ukuran, material bahan yang digunakan harga produk dan lain sebagainya. 


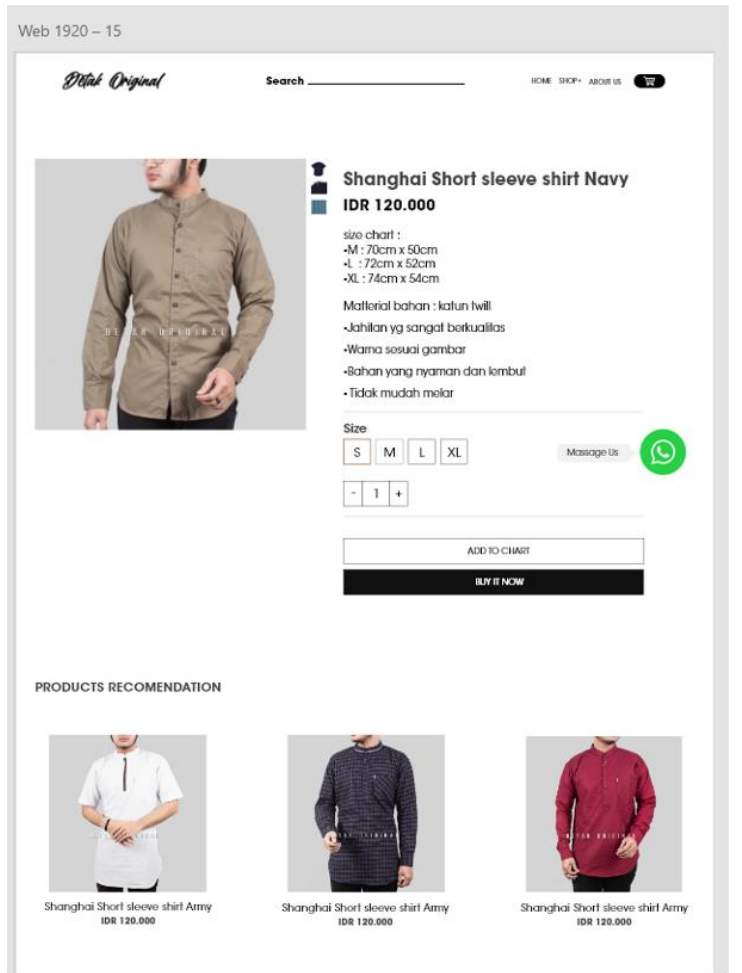

Gambar 6 Tampilan halaman detail produk

Setelah menetapkan pilihan, pengunjung dapat mengisi beberapa informasi yang dibutuhkan pada halaman pesanan. Pada halaman ini ditentukan jumlah yang harus dibayar oleh pembeli, kemana barang yang dibeli akan dikirim, bagaimana metode pembayaran dan informasi lainnya.

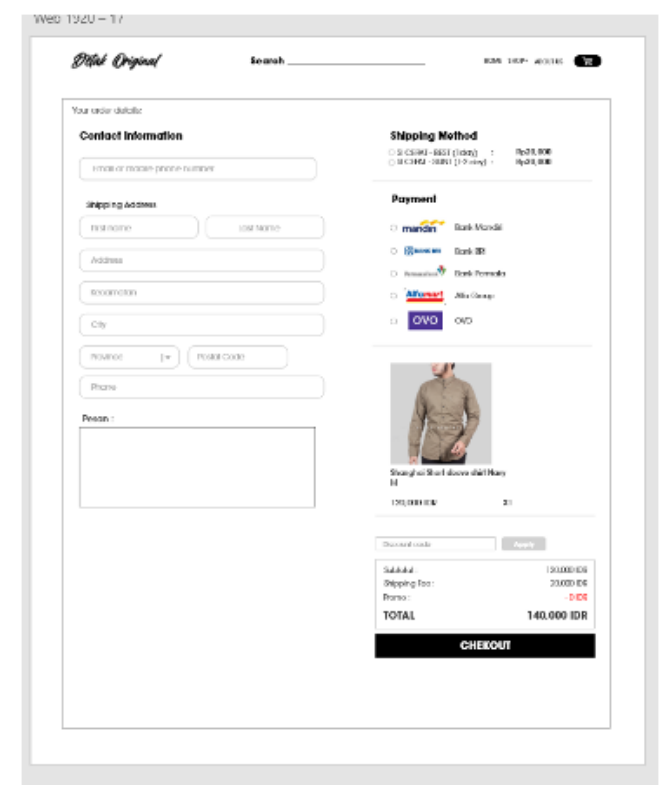

Gambar 7 Tampilan halaman pesanan

Setelah mengisi informasi pada halaman pesanan, pengunjung akan diarahkan pada halaman pembayaran. Pada halaman ini ditampilkan informasi bagaimana harus membayar, dan status pembayaran kita. Setelah membayar pengunjung atau pembeli hanya tinggal memantau status pengiriman kemudian menunggu barang tiba.

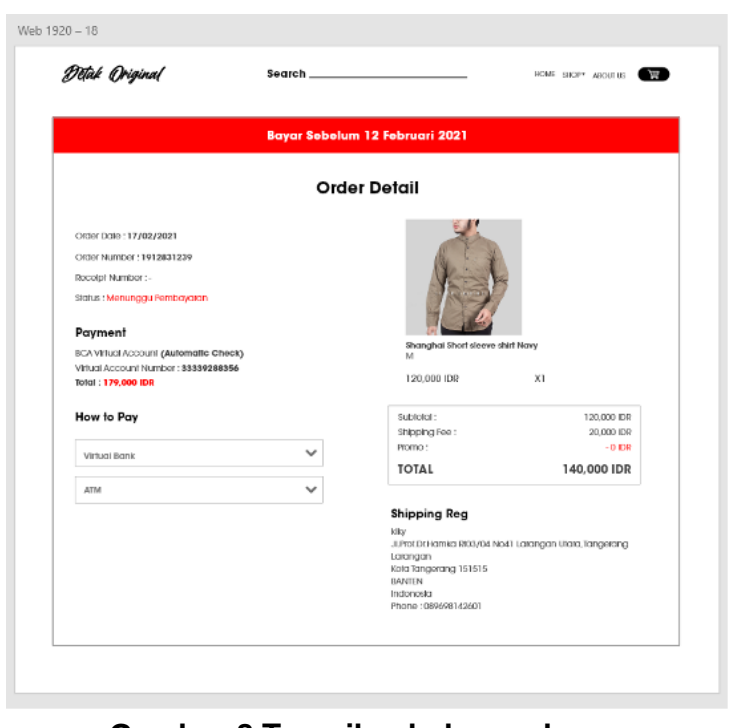

Gambar 8 Tampilan halaman bayar

Dengan beroperasi website tersebut dapat mengatasi masalah yang dialami oleh Toko Detak Original dan menambah value berupa profit penjualan serta menambah kepercayaan pelanggan.

\section{KESIMPULAN}

Pada penelitian ini dibangun sebuah website Toko Detak Original berbasis ECommerce yang dapat menampilkan profile produk yang dijual dan menangani penjualan secara online. Dengan website tersebut Toko Detak Original dapat mengatasi masalah yang dialami, karena pelanggan dapat melihat produk secara online dengan device yang terhubung dengan internet, melakukan pembelian langsung pada halaman website tanpa harus datang ke bangunan toko, tentunya hal ini membuat suatu aktivitas menjadi sangat efisien dan meningkatkan profit bagi Toko detak Original.

Selain itu dengan fitur yang tersedia pada halaman back-end website memudahkan 
pemilik mengatur website seperti tampilan, memantau ketersediaan stok produk, memantau transaksi penjualan dan membuat laporan dengan mudah dan akurat.

\section{REFERENSI}

[1]. A. C. Prof. Dr. Sri Mulyani. (2016). Metode Analisis dan Perancangan Sistem. Bandung: Abdi Sistematika.

[2]. Djahir dan Pratita. (2015). Sistem Informasi Manajemen. Yogyakarta: CV. Budi Utama.

[3]. Fathansyah. (2015). Basis Data. Bandung: Informatika.

[4]. Ginting, E. (2013). Sistem informasi Penjualan Berbasis Web (E-Commerce) Menggunakan Joomla Pada Mutiara Fashion. Fakultas Teknik Universitas Widyatama. Bandung. http://library.stmikgici.ac.id/skripsi/161300 059.pdf

[5]. Hutahaean. (2015). Konsep Sistem Informasi. Yogyakarta: CV. Budi Utama.

[6]. Julianto, E. (2018). Sistem Informasi Penjualan Tas

Berbasis Web Pada Toko Tas Trisna. Bina Sarana Informatika. Jakarta. https://repository.bsi.ac.id/index.php/repo/ viewitem/6045

[7]. Mulyani, A. (2016). Sistem Informasi Manajemen Rumah Sakit: Analisis dan Perancangan. Bandung: Abdi Sistematika.

[8]. Nur R., dan Suyuti M. A. (2018). Perancangan Mesin-Mesin Industri. Yogyakarta: Deepublish.

[9]. Rachman R. A., Beny dan Fernando E. (2017). Perancangan E-Commerce Berbasis Website Pada Toko Mirabella Batik Jambi. Universitas Dinamika Bangsa. Jambi.

http://repository.unama.ac.id/id/eprint/778
Jurnal IImu Komputer dan Informatika Vol 2 № 2 p-ISSN: $2776-7418$ e-ISSN: 2746-508X

[10]. Romney B. M. dan Steinbart J. P. (2014). Sistem Informasi Akuntansi: Accounting Information Systems (Edisi 13). Prentice Hall.

[11]. Romney, Marshall B. dan Steinbart,. (2015). Sistem Informasi Akuntansi. Edisi 13. Jakarta: Salemba Empat.

[12]. Rosa A.S., dan Shalahuddin, M. (2015). Rekayasa Perangkat Lunak Terstruktur dan Berorientasi Objek. Bandung: Informatika Bandung.

[13]. Sofyan A. A., Gustomi L. F., dan Fitrianto S. (2016). Perancangan Sistem Informasi Perencanaan dan Pengendalian Bahan Baku Pada PT. Hema Medhajaya. Jurnal Sisfotek Global. Tangerang. 